\title{
What is Linked between the Green Human Resources Practice with Sustainability Business?
}

\author{
Lenny C Nawangsari, Ahmad H Sutawijaya
}

\begin{abstract}
Micro, Small and Medium Enterprises (MSMEs) are economic divisions that have an essential part in economic growth in Indonesia. One of the strong characteristics of MSMEs is that they are labor intensive, using simple and easy to understand technology. Green HRM is a labor management system that is implemented to reduce negative impacts on the natural environment or increase the positive influence of the natural environment on the performance of MSMEs. This analysis intends to analyze the role of Green HRM related to business continuity and examine the practice of Green HRM in management functions, namely green staffing and selection, green training and development (GT \& D), green performance management and appraisal (GPM \& $A)$, green reward and compensation (GR \& C) \& green employee retention (GER) related to Green Performance in MSMEs. The research outcomes proved that Green HRM practices improve Green Performance related to business sustainability in MSMEs.
\end{abstract}

Index Terms: Green Human Resources Management, Green Performance, Competitive Advantage, Sustainability Business, MSMEs.

\section{INTRODUCTION}

Globalization has resulted in increased environmental impact, organizations globally are expected to be responsible for environmental management. GHRM emerged as the impact of a business sustainability strategy focused on Green Performance. GHRM implementation is very necessary to support the sustainability of the organization through its activities so that it has an impact on environmental care, social welfare and economic improvement in the organization. Some functions in Green Human Resources Management are related to GR \& S, GPM, GT \& D, GRS \& GER.

In managing HRM that focuses on the environment, there is a need for strategies that are integrated with business strategies (Ahmad, 2015). Aligning systematic human resource practices to place workers in the control of environmental management (Charbel, 2011) and GHRM Practices is a set of management processes implemented by businesses to respond to shareholder demands on conservation matters (Macro et.al, 2015). A good implementation of GHRM will improve business excellence (Jackson et al., 2011) related to the implementation in MSMEs, the concept of Green Human Resources Management is needed (Lenny, 2018). Besides, that organizational behavior related to GHRM practices will

Revised Manuscript Received on September 22, 2019

Lenny C awaNngsari, Magister Management, Universitas Mercubuana, lenny.nawangsari@gmail.com

Ahmad H Sutawijaya, Doctoral Management, Universitas Mercubuana,ahsuta69@gmail.com encourage employees to carry out pro-environmental behavior (Mishra, 2017).

Based on observations in the field, many MSMEs lack superior human resources to manage their business. Most HR in choosing workplaces begins to pay attention to the company's image related to its concern with the environment. In connection with this, MSMES needs to develop a strategy and managing Human Resources based on the environment related to planning, recruiting, training \& developing, and maintaining its HR to become one of the value added of its business.

\section{LITERATURE REVIEW}

\section{A. Green Human Resources Management}

Opatha \& Anton (2014) and Jabbour et al (2010) which stated that Green Human Resources Management is all actions involved in the growth, application, and continuing conservation of an organization that intends to make personnel of the organization green ", while Renwick et al, (2008) stated that Green HRM is the integration of management of the corporate ecosystem into human resource management. Based on some of the opinions, it can be determined that Green HRM is a GHRM program, process, and technique that is truly implemented in the firm to lessen adverse ecological effects and improve the company's environmentally friendly performance.

Some of the purposes of GHRM are:

\section{Green recruitment}

Green Recruitment can be described as the procedure of recruiting people with expertise, abilities, attitudes, and manners that recognize with the conservation management system in a company.

\section{Green performance management}

GPM is a practice where personnel are asked to improve their career abilities that assist accomplish organizational objectives and goals in a safer way.

\section{Green training and development}

GT \& D educates and trains personnel to masterwork processes that save energy, lessen garbage, use ecological understanding in organizations, and deliver opportunities to involve personnel in solving ecological problems.

\section{Green compensation}

In the perspective of GHRM, GC can be considered a prospective tool to support environmentally friendly endeavors in businesses. In agreement with a premeditated method to respect and managing, contemporary companies develop a incentive system to promote environmentally friendly schemes initiated by their staffs

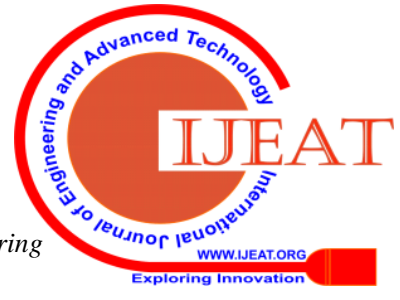




\section{Green employee relations}

GER is an HRM facet that is related to building friendly boss-worker relationships. This connection facilitates employee motivation and enthusiasm and increases productivity

\section{B. Green performance}

Measuring GP according to Chen et al. (2014) includes several things, among others: (1) Selection of product resources that produce the minimum quantity, the least use of resources and which can be recycled for product development or product design; (2) Effectively reducing emissions of hazardous materials or waste; (3) Recycling waste and emissions needed to be processed and reused; (4) Reducing consumption of water, electricity, coal or oil; and (5) operating processes that reduce the use of raw materials.

\section{Competitive Advantage}

Fred David (2011) describes competitive advantage as "everything firms do safer than competitor firms". When a firm can accomplish somewhat that a competitor firm cannot do or has something a competing firm aims, then it can signify a competitive advantage. Whereas according to Porter, Competitive advantage is the aptitude acquired via the qualities and assets of a firm to have a superior accomplishment than other firms in the similar trade or market.

Several previous studies related to Green Human Resources Management (GHRM) were conducted by A P Sarode (2016) which carried out an assessment of GHRM practices such as staffing, selection, preparation, and advancement, retention in several industries. A similar study was also conducted by Hiba A et al. (2016) which proved the influence of GHRM procedures in business companies on Environmental Performance in Palestine. While Jie Shen.et.al (2016) examines GHRM influences employee performance which is mediated by organizational identification while Deepak (2015) examines practical GHRM practices that have yielded encouraging results on Green Environmental Performance. The Guiyao Tang (2017) study also measures GHRM Practices associated with environmental performance. The results of these studies are in line with Macro et.al s research (2015). Whereas Adimuthu Research (2017) states that GHRM Practices have a large role in helping to change their specific organizations to green. The Bihal Research (2018) proves that GHRM practices positively influence employee pro-conservation behavior. Douglas et.al (2012) in his research proved that the practice of GHRM influences employee motivation to become involved in environmental performance.

Based on the study of the theory and previous research then Hypothesis Testing Research as follows:

H1: Green Recruitment and selection positively and significantly effects Green Performance

$\mathrm{H} 2$ : Green Training and development positively and significantly effects Green Performance

H3: Green Performance management and appraisal positively and significantly effects Green Performance

H4: Green Reward and compensation positively and significantly effects Green Performance

H5: Green Employee retention positively and significantly effects Green Performance

H6: Green Performance positively and significantly effects Competitive advantage

H7: Green Recruitment and selection positively and significantly influences Competitive advantage

H8: Green Training and development positively and significantly influences Competitive advantage

H9: Green Performance management and appraisal positively and significantly effects Competitive advantage

H10: Green Reward and compensation positively and significantly effects Competitive advantage

H11: Green Employee retention positively and significantly effects Competitive advantage

H12: Green Recruitment and selection positively and significantly influences Competitive advantage through Green Performance

H13: Green Training and development positively and significantly influences Competitive advantage through Green Performance

H14: Green Performance management and appraisal positively and significantly effects Competitive advantage through Green Performance

H15: Green Performance management and appraisal positively and significantly effects Competitive advantage through Green Performance

H16: Green Employee retention positively and significantly effects Competitive advantage through Green Performance

Fig 1. Research Model (See Appendix - A)

\section{METHODOLOGY}

This study utilizes a quantitative methodology with a survey performed on employees of MSME around Jakarta with a overall sample of 100 individuals. Each variables in the survey was assessed utilizing a Likert scale of $1-5$.

\section{RESULT AND FINDING}

\section{A. Result}

\section{Generalized Structured Component Analysis / GSCA}

The Inferential statistical assessment technique is to assess the experimental model and hypothesis in research. This exploration is using Generalized Structured Component Analysis (Solimun,2013). The assessment stages are:

\section{1) Testing Measurement Model}

Testing the research measurement model aims to assess the indicator variables (observed variables) that indicate non measurable latent variables. The assessment of the indicators utilized is tested to give meaning to the symbols given to the latent variables. The experimental assessment aims to confirm the model and consistency of the constructs that reflect the parameters of latent variables constructed on empirical theory and study. There are 3 standards to evaluate the measurement model: 


\section{2) Convergent validity}

This test explains the correlation measure amidst the reflective indicator score as well as the latent variable score. For considers the loading of $\geq 0.50$ valid. Findings of the test can be observed in Table 1

Table 1. Result Test Validity Convergent

\begin{tabular}{|c|c|c|c|c|}
\hline No & Variable & $\begin{array}{c}\text { Indicato } \\
\text { rs }\end{array}$ & Loading & Note \\
\hline \multirow[t]{5}{*}{1} & $\begin{array}{l}\text { Green Recruitment \& } \\
\text { Selection }\end{array}$ & (X1.1) & 0.523 & Valid \\
\hline & & (X1.2) & 0.676 & Valid \\
\hline & & (X1.3) & 0.589 & Valid \\
\hline & & (X1.4) & 0.754 & Valid \\
\hline & & (X1.5) & 0.622 & Valid \\
\hline \multirow[t]{3}{*}{2} & $\begin{array}{l}\text { Green Training \& } \\
\text { Development }\end{array}$ & $(\mathrm{X} 2.1)$ & 0.578 & Valid \\
\hline & & $(\mathrm{X} 2.2)$ & 0.858 & Valid \\
\hline & & $\begin{array}{l}(\mathrm{X} 2.3) \\
(\mathrm{X} 2.4)\end{array}$ & $\begin{array}{l}0.584 \\
0.596\end{array}$ & $\begin{array}{l}\text { Valid } \\
\text { Valid }\end{array}$ \\
\hline \multirow[t]{2}{*}{3} & $\begin{array}{l}\text { Green Performance } \\
\text { Management }\end{array}$ & (X3.1) & 0.654 & Valid \\
\hline & \& Appraisal & $\begin{array}{l}\text { (X3.2) } \\
\text { (X3.3) } \\
\text { (X3.4) } \\
(X 3.5)\end{array}$ & $\begin{array}{l}0.651 \\
0.640 \\
0.853 \\
0.523\end{array}$ & $\begin{array}{l}\text { Valid } \\
\text { Valid } \\
\text { Valid } \\
\text { Valid }\end{array}$ \\
\hline \multirow[t]{2}{*}{4} & $\begin{array}{l}\text { Green Reward \& } \\
\text { compensation }\end{array}$ & (X4.1) & 0.844 & Valid \\
\hline & & $\begin{array}{l}(\mathrm{X} 4.2) \\
(\mathrm{X} 4.3)\end{array}$ & $\begin{array}{l}0.700 \\
0.563\end{array}$ & $\begin{array}{l}\text { Valid } \\
\text { Valid }\end{array}$ \\
\hline \multirow[t]{2}{*}{5} & $\begin{array}{l}\text { Green Employee } \\
\text { Retention }\end{array}$ & (X5.1) & 0.739 & Valid \\
\hline & & $\begin{array}{l}(X 5.2) \\
(X 5.3) \\
(X 5.4)\end{array}$ & $\begin{array}{l}0.839 \\
0.530 \\
0.506\end{array}$ & $\begin{array}{l}\text { Valid } \\
\text { Valid } \\
\text { Valid }\end{array}$ \\
\hline \multirow[t]{2}{*}{6} & Green Performance & $\begin{array}{l}(\mathrm{Y} 1.1) \\
(\mathrm{Y} 1.2)\end{array}$ & $\begin{array}{l}0.505 \\
0.595\end{array}$ & $\begin{array}{l}\text { Valid } \\
\text { Valid }\end{array}$ \\
\hline & & $\begin{array}{l}(\mathrm{Y} 1.1) \\
(\mathrm{Y} 1.2)\end{array}$ & $\begin{array}{l}0.671 \\
0.733\end{array}$ & $\begin{array}{l}\text { Valid } \\
\text { Valid }\end{array}$ \\
\hline \multirow[t]{2}{*}{7} & $\begin{array}{l}\text { Competitive } \\
\text { Advantage }\end{array}$ & (Y2.1) & 0.785 & Valid \\
\hline & & $\begin{array}{l}(\mathrm{Y} 2.2) \\
(\mathrm{Y} 2.3) \\
(\mathrm{Y} 2.4)\end{array}$ & $\begin{array}{l}0.516 \\
0.746 \\
0.550\end{array}$ & $\begin{array}{l}\text { Valid } \\
\text { Valid } \\
\text { Valid }\end{array}$ \\
\hline
\end{tabular}

The table explains the estimated value in each indicator variable at loading $\geq 0.50$. Hence, it is determined that the variable is acceptable.

\section{3) Discriminant validity}

Valid instrument discriminant validity in testing $\sqrt{A V E}$ corresponds to larger than the variables correlation coefficient. Test findings are observed in table 2.

Table 2. Test Result Validity Discriminant

\begin{tabular}{|c|c|c|c|c|c|c|c|c|}
\hline & AVE & X1 & X2 & X3 & X4 & X5 & Y1 & Y2 \\
\hline X1 & $\mathbf{0 . 5 7 3}$ & 1 & 0.102 & 0.407 & 0.416 & 0.474 & 0.257 & 0.054 \\
\hline X2 & $\mathbf{0 . 5 6 2}$ & 0.102 & 1 & 0.367 & 0.358 & 0.333 & 0.260 & 0.117 \\
\hline X3 & $\mathbf{0 . 6 5 3}$ & 0.407 & 0.367 & 1 & 0.472 & 0.602 & 0.261 & 0.104 \\
\hline X4 & $\mathbf{0 . 5 0 7}$ & 0.416 & 0.358 & 0.472 & 1 & 0.507 & 0.227 & 0.190 \\
\hline X5 & $\mathbf{0 . 5 4 6}$ & 0.474 & 0.333 & 0.602 & 0.507 & 1 & 0.422 & 0.043 \\
\hline Y1 & $\mathbf{0 . 5 3 9}$ & 0.257 & 0.260 & 0.261 & 0.227 & 0.422 & 1 & 0.294 \\
\hline Y2 & $\mathbf{0 . 5 3 6}$ & 0.054 & 0.117 & 0.104 & 0.190 & 0.043 & 0.294 & 1 \\
\hline
\end{tabular}

Table 2 clarifies $\sqrt{ }$ AVE in each research variables is higher than the correlation coefficient. Hence, the research tool has discriminant validity.

4) Internal Consistency

An instrument is said to be reliable when the alpha value >
0.60. The findings of the reliability test are given in Table 3 .

Table 3. Reliability Test Results

\begin{tabular}{lcl}
\hline \multicolumn{1}{c}{ Variables } & Alpha & Note \\
\hline $\begin{array}{l}\text { Green Recruitment \& Selection } \\
\text { (X1) }\end{array}$ & 0.751 & Reliable \\
$\begin{array}{l}\text { Green Training \& } \\
\text { Development (X2) }\end{array}$ & 0.786 & Reliable \\
$\begin{array}{l}\text { Green Performance } \\
\text { Management \& Appraisal (X3) }\end{array}$ & 0,860 & Reliable \\
$\begin{array}{l}\text { Green Reward \& compensation } \\
\text { (X4) }\end{array}$ & 0,713 & Reliable \\
$\begin{array}{l}\text { Green Employee Retention } \\
\text { (X5) }\end{array}$ & 0,787 & Reliable \\
Green Performance (Y1) & 0.799 & Reliable \\
Competitive Advantage (Y2) & 0.754 & Reliable \\
\hline
\end{tabular}

Table 3 displays that each the variables produce values alpha $>0.60$ so it is concluded that research instruments has valid internal consistency.

\section{5) Evaluation of Goodness-of-fit Structural Model and Overall Model}

Goodness-of-fit tests on GSCA analysis consist of fit model models and overall models that can be evaluated from FIT, AFIT, GFI (Unweighted least-squares) and SRMR (Standardized root mean square residual) values. The result of the analysis with GSCA method is given in Table 4.

Table 4. Evaluation of Goodness-of-fit Structural Model and Overall Model on GSCA

\begin{tabular}{lc}
\hline & MODEL FIT \\
\hline FIT & 0,448 \\
AFIT & 0,433 \\
GFI & 0,981 \\
SRMR & 0,187 \\
NPAR & 65 \\
\hline
\end{tabular}

FIT value of 0,448 and AFIT 0,433 indicates that GR \& S, GT \& D, GPM \& A, GER and GP influence Competitive Advantage $43,3 \%$, while the rest $56,7 \%$ is influenced by other variables. The GFI value of 0.981 is greater than the cutoff value $\geq 0.90$ which suggests that the model is in decent criteria. The findings of the assessment can be said sufficient to meet the conditions of Goodness-Of-Fit.

6) Hypothesis testing

Hypothesis Testing \& Coefficient of Direct \& Indirect Effect Line

Hypothesis testing and path coefficient of direct influence amidst GR \& S, GT \& D, GPM \& A, GER to GP and Competitive Advantage. Direct effect can be noticed from the value of path coefficient and critical point $(\mathrm{CR} *)$ is significant at $\alpha=0,05$. Test findings show direct impact amongst variables in table 5 .

Table 5. Coefficient Direct Effect and Hypothesis Testing

\begin{tabular}{cccc}
\hline Direct Correlation & Path Coef & CR & Note \\
\hline $\mathrm{X} 1->\mathrm{Y} 1$ & 0.100 & $8.98^{*}$ & Significant \\
$\mathrm{X} 2->\mathrm{Y} 1$ & 0.157 & $9.63^{*}$ & Significant \\
$\mathrm{X} 3->\mathrm{Y} 1$ & 0.039 & $8.1^{*}$ & Significant
\end{tabular}

\section{Published By:}




$\begin{array}{lccc}\text { X4->Y1 } & 0.037 & 0.38 & \text { Not significant } \\ \text { X5->Y1 } & 0.365 & 14.29^{*} & \text { Significant } \\ \text { Y1->Y2 } & 0.332 & 14.98^{*} & \text { Significant } \\ \text { X1->Y2 } & 0.040 & 0.56 & \text { Not significant } \\ \text { X2->Y2 } & 0.010 & 0.17 & \text { Not significant } \\ \text { X3->Y2 } & 0.069 & 2.92^{*} & \text { Significant } \\ \text { X4->Y2 } & 0.211 & 2.05^{*} & \text { Significant } \\ \text { X5->Y2 } & 0.230 & 4.78^{*} & \text { Significant }\end{array}$

Note $*=$ significant to $\alpha=0.05$

On the basis above evaluation following are the results:

H1: Green Recruitment and selection positively and significantly effect Green Performance

The outcome of the assessment reveals that the coefficient value of the direct influence of Green Recruitment to Green Performance is 0.100 with critical point $8.98^{*}$, meaning a significant influence of Green Recruitment to Green Performance. This indicates that hypothesis 1 which states "Green Recruitment and selection positively and significantly effects Green Performance" is fulfilled. The analysis results indicate with the increase in Green Recruitment can increase Green Performance MSMEs.

H2: Green Training and development positively and significantly effects Green Performance

The analysis findings state the coefficient value of direct influence Green Training and development to Green Performance of 0.157 with a critical point $9.63^{*}$, means Green Training \& development significantly influences Green Performance. Hypothesis 2 is fulfilled. The analysis results imply that Green Training and development increase will affect the increase in Green Performance MSMEs

H3: Green Performance management and appraisal positively and significantly effects Green Performance

The analysis findings show that the coefficient of Green Performance management and appraisal direct effect Green Performance is 0.039 with critical point $8.1^{*}$, means Green Performance management and appraisal significantly influence Green Performance. Hypothesis 3 is fulfilled. This indicates that good Green Performance management and appraisal in the organization will increase Green Performance MSMEs

H4: Green Reward and compensation positively and significantly effects Green Performance

The analysis findings state the acquisition value of the coefficient of direct influence Green Reward and compensation to Green Performance of 0.037 with a critical point 0,38 , means Green Reward and compensation significantly influences Green Performance. Hypothesis 4 is not accepted.

H5: Green Employee retention positively and significantly effects Green Performance

The analysis findings show the value of the coefficient of direct influence Green Employee retention to Green Performance of 0.365 with a critical point of $14.29^{*}$, means Green Employee retention significantly influences Green Performance. Hypothesis 5 is fulfilled. This indicates that good implementation of Green Employee retention can improve Green Performance in MSMEs.

H6: Green Performance positively and significantly effects Competitive advantage

The analysis findings state the coefficient value of direct influence Green Performance to Competitive Advantage of 0.332 with a critical point $14.98^{*}$, means Green Performance significantly influences Competitive Advantage. Hypothesis 6 is acknowledged. The outcomes of this study suggest that a rise in Green Performance will affect the increase in Competitive Advantage MSMEs

H7: Green Recruitment and selection positively and significantly effects Competitive advantage

The analysis findings reveals that the coefficient value of the direct influence of Green Recruitment to Competitive advantages 0.040 with critical point 0.56 , means Green Recruitment does not significantly influences Competitive advantage. Hypothesis 7 is not accepted.

H8: Green Training and development positively and significantly effects Competitive advantage

The analysis findings state the coefficient value of direct influence Green Training and development to Competitive advantage of 0.010 with a critical point $0.17^{\prime}$ means Green Training and development does not significantly influence Competitive advantage. Hypothesis 8 is not accepted

H9: Green Performance management and appraisal positively and significantly effects Competitive advantage

The analysis findings shows that the coefficient of Green Performance management and appraisal direct effect Competitive advantage is 0.069 with critical point $2.92 \%$, means Green Performance management and appraisal significantly influence Competitive advantage. Hypothesis 9 is accepted. This indicates that good Green Performance management and appraisal in the organization will increase Competitive advantage MSMEs

H10: Green Reward and compensation positively and significantly effects Competitive advantage

The analysis findings state the acquisition value of the coefficient of direct influence Green Reward and compensation to Competitive advantage of 0.211 with a critical point $2.05^{*}$, means Green Reward and compensation significantly influence Competitive advantage. Hypothesis 10 is accepted.

H11: Green Employee retention positively and significantly effects Competitive advantage

The analysis findings show the value of the coefficient of direct influence Green Employee retention to Competitive advantage of 0.230 with a critical point of $4.78^{*}$, means significantly influence Competitive advantage. Hypothesis 11 is accepted. This indicates that good implementation of Green Employee retention can improve Competitive advantage in MSMEs.

Table 6. Coefficient Indirect Effect and Hypothesis Testing

\begin{tabular}{|c|c|c|c|c|}
\hline $\begin{array}{c}\text { Indirect } \\
\text { Influence }\end{array}$ & \multicolumn{2}{|c|}{ Direct Influence } & $\begin{array}{c}\text { Indirect } \\
\text { Influenc } \\
\text { e }\end{array}$ & Note \\
\hline $\mathrm{X} 1 \rightarrow \mathrm{Y} 1 \rightarrow \mathrm{Y} 2$ & $\begin{array}{c}\mathrm{X} 1 \rightarrow \mathrm{Y} 1= \\
0,100\end{array}$ & $\begin{array}{c}\mathrm{Y} 1 \rightarrow \mathrm{Y} 2= \\
0,332\end{array}$ & $0.033 *$ & Significant \\
\hline
\end{tabular}




\begin{tabular}{|c|c|c|c|c|}
\hline $\mathrm{X} 2 \rightarrow \mathrm{Y} 1 \rightarrow \mathrm{Y} 2$ & $\begin{array}{c}\mathrm{X} 2 \rightarrow \mathrm{Y} 1= \\
0,157\end{array}$ & $\begin{array}{c}\mathrm{Y} 1 \rightarrow \mathrm{Y} 2= \\
0,332\end{array}$ & 0.052 & $\begin{array}{c}\text { Not } \\
\text { Significant }\end{array}$ \\
\hline $\mathrm{X} 3 \rightarrow \mathrm{Y} 1 \rightarrow \mathrm{Y} 2$ & $\begin{array}{c}\mathrm{X} 3 \rightarrow \mathrm{Y} 1= \\
0.039\end{array}$ & $\begin{array}{c}\mathrm{Y} 1 \rightarrow \mathrm{Y} 2= \\
0,332\end{array}$ & $0.013^{*}$ & Significant \\
\hline $\mathrm{X} 4 \rightarrow \mathrm{Y} 1 \rightarrow \mathrm{Y} 2$ & $\begin{array}{c}\mathrm{X} 4 \rightarrow \mathrm{Y} 1= \\
0,037\end{array}$ & $\begin{array}{c}\mathrm{Y} 1 \rightarrow \mathrm{Y} 2= \\
0,332\end{array}$ & $0.012 *$ & Significant \\
\hline $\mathrm{X} 5 \rightarrow \mathrm{Y} 1 \rightarrow \mathrm{Y} 2$ & $\begin{array}{c}\mathrm{X} 5 \rightarrow \mathrm{Y} 1= \\
0,365\end{array}$ & $\begin{array}{c}\mathrm{Y} 1 \rightarrow \mathrm{Y} 2= \\
0,332\end{array}$ & 0.121 & $\begin{array}{c}\text { Not } \\
\text { Significant }\end{array}$ \\
\hline
\end{tabular}

Note $*=$ significant at $\alpha=0.05$

H12: Green Recruitment and selection positively and significantly effects Competitive advantage through Green Performance

The analysis findings stated that the value of a coefficient of an indirect influence of Green Recruitment and selection to Competitive Advantage through Green Performance is 0,033*, means Green Recruitment and selection significantly influence Competitive Advantage through Green Performance. Hypothesis 12 is acknowledged. The result of this assessment shows that Green Performance mediates the association between Green Recruitment and selection and Competitive Advantage MSMEs

H13: Green Training and development positively and significantly effects Competitive advantage through Green Performance

The analysis findings state value of the coefficient of indirect influence Green Training and development to Competitive Advantage through Green Performance is 0.052 , meaning Green Training and development does not significantly influence Competitive advantage through Green Performance. Hypothesis 13 is not accepted.

H14: Green Reward and compensation positively and significantly effects Competitive advantage through Green Performance

The analysis findings stated that the value of a coefficient of an indirect influence of Green Reward and compensation to Competitive Advantage through Green Performance is 0,013*, meaning Green Reward and compensation significantly influence Competitive Advantage through Green Performance. Hypothesis 14 is acknowledged. The result of this assessment shows that Green Performance mediates the association between Green Performance management and Competitive Advantage MSMEs

H15: Green Performance management and appraisal positively and significantly effects Competitive advantage through Green Performance

The analysis findings stated that the value of a coefficient of an indirect influence of Green Performance management and appraisal to Competitive Advantage through Green Performance is $0.012 *$, meaning Green Performance management and appraisal significantly influence Competitive Advantage through Green Performance. Hypothesis 15 is acknowledged. The result shows that Green Performance mediates the association among Green Recruitment and selection and Competitive Advantage MSMEs

H16: Green Employee retention positively and significantly effects Competitive advantage through Green Performance

The analysis findings state value of the coefficient of indirect influence Green Employee retention to Competitive Advantage through Green Performance is 0.052, meaning

Green Employee retention does not significantly influence Competitive advantage through Green Performance. Hypothesis 13 is not accepted.

On the basis of above mentioned assessment, it is proved that:

1. Green Performance variable as the mediator variable in the correlation of Green Recruitment and selection to Competitive advantage

2. Green Performance variable as the mediator variable in the correlation of Green Performance management and appraisal to Competitive advantage

3. Green Performance variable as the mediator variable in the correlation of Green Reward and compensation to Competitive advantage

7) Path Analysis Model

On the basis of the analysis, the path model of the relationship among the variables is depicted in Figure 2.

Fig. 2. "Path Analysis Model' (See Appendix B)

\section{Loading Factor Test}

It is utilized to locate out the greatest variable indicator. The score of the loading factor signifies the IV as the corresponding indicator has a leading impact to indicate its DV. The result of the loading factor of every indicator is displayed in the following table.

Table 7. Recapitulation of Estimate Loading

\begin{tabular}{|c|c|c|c|}
\hline No & Variable & Indicators & Loading \\
\hline \multirow[t]{3}{*}{1} & $\begin{array}{l}\text { Green } \\
\text { Recruitment \& } \\
\text { Selection (X1) }\end{array}$ & (X1.1) Design work focuses on green & 0.523 \\
\hline & & (X1.2) Job description focus on green & 0.676 \\
\hline & & $\begin{array}{l}\text { (X1.3) green behavioral criteria for } \\
\text { candidate } \\
\quad \text { employees } \\
\text { (X1.4) acceptance priority for } \\
\text { environmentally } \\
\quad \text { conscious candidates } \\
\text { (X1.5) use the online recruitment system }\end{array}$ & 0.754 \\
\hline
\end{tabular}

\footnotetext{
Green

2 Training \&

Development

(X2.1) induction which emphasizes environmental problems
} (X2)

0.578

(X2.2) training material available online (X2.3) conduct training on environment management

(X2.4) on training needs analysis pay

Green

3 Performance Management

\& Appraisal

(X3) attention to training on the environment

0.858

0.584

(X3.1) employees know the target to contribute to environmental management

(X3.2) management includes

environmental indicators in performance appraisal

(X3.3) combining the objectives and targets of environmental management in the organization's work evaluation system (X3.4) The company provides feedback on the results of performance appraisal (X3.5) the existence of a programmed performance appraisal system 


\begin{tabular}{|c|c|c|c|}
\hline No & Variable & Indicators & Loading \\
\hline \multirow[t]{2}{*}{4} & $\begin{array}{l}\text { Green Reward } \\
\& \\
\text { compensation }\end{array}$ & $\begin{array}{l}\text { (X4.1) reward system which is associated } \\
\text { with Green Performance }\end{array}$ & 0.844 \\
\hline & & $\begin{array}{l}\text { (X4.2) the reward for achieving } \\
\text { environmental performance } \\
\text { (X4.3) The existence of a programmed } \\
\text { compensation system }\end{array}$ & $\begin{array}{l}0.700 \\
0.563\end{array}$ \\
\hline \multirow[t]{4}{*}{5} & $\begin{array}{l}\text { Green } \\
\text { Employee } \\
\text { Retention }\end{array}$ & (X5.1) good career system & 0.739 \\
\hline & & $\begin{array}{l}\text { (X5.2) provide openings for personnel to } \\
\text { participate in managing green } \\
\text { management in the workplace }\end{array}$ & 0.839 \\
\hline & & (X5.3) conducive work situation & 0.530 \\
\hline & & $\begin{array}{l}\text { (X5.4) management supports employees } \\
\text { to improve green behavior }\end{array}$ & 0.506 \\
\hline \multirow[t]{5}{*}{6} & $\begin{array}{l}\text { Green } \\
\text { Performance }\end{array}$ & $\begin{array}{l}\text { (Y1.1) cooperation with the green } \\
\text { supplier }\end{array}$ & 0.505 \\
\hline & & $\begin{array}{l}\text { (Y1.2) using environmentally friendly } \\
\text { materials }\end{array}$ & 0.595 \\
\hline & & $\begin{array}{l}\text { (Y1.3) reducing waste and recycling in the } \\
\text { production process }\end{array}$ & 0.671 \\
\hline & & $\begin{array}{l}\text { (Y1.4) reducing waste and recycling in the } \\
\text { production process }\end{array}$ & 0.733 \\
\hline & Competitive & & \\
\hline \multirow[t]{4}{*}{7} & Advantage & (Y2.1) product and service quality & 0.785 \\
\hline & & (Y2.2) improvement in production costs & 0.516 \\
\hline & & (Y2.3) product design innovation & 0.746 \\
\hline & & (Y2.4) customer satisfaction & 0.550 \\
\hline
\end{tabular}

Note $^{*}=$ Value loading factor largest / highest

The strongest indicator of Green Recruitment and selection measurement is acceptance priority for environmentally conscious candidates with loading factor 0.754. Training material available online indicators as the strongest measure of Green Training and development variables with 0.858 loading factor. The company provides feedback on the results of the performance appraisal indicator as to the strongest measure of Green Performance management and appraisal variable with loading factor 0.853. The strongest indicator of Green Reward \& compensation variable is a) reward system which is associated with Green Performance with 0.844 loading factor and provides openings for personnel to partake in managing green as the strong indicator of Green Employee Retention with loading factor 0.839. reducing waste and recycling in the production process indicators as the strongest measure of Green Performance variable with 0.733 loading factor While the strongest indicator of Competitive Advantage is product and service quality with loading factor 0.785 .

\section{B. Findings}

1) Green Recruitment and selection positively and significantly effects Green Performance.

The findings are in accordance with research done by Hiba et.al (2016.) which signify that GHRM affects Green Performance. The result of research proves that the most influential Green Recruitment and selection Characteristic is is acceptance priority for environmentally conscious candidates, with the presence of HR who have a concern for the environment, it will make it easier for MSMEs to

\section{implement GHRM.}

2) Green Training and development positively and significantly effects Green Performance.

The outcomes of this exploration are in accordance with the results of A P Sarode (2016) study which affirms that GHRM effects Green Performance. The outcomes showed Green Training and development of MSME employees are good enough. The most influential characteristic of Green Training and development is the characteristic of Training material available online. In the current digital era, HR training in MSMEs is mostly done informally. For example, learning through online media and sharing through WhatsApp and Youtube digital media.

3) Green Performance management and appraisal positively and significantly effects Green

Performance

These results substantiate the results of previous research conducted by Guiyao Tang (2017). The results found that the dominant characteristic of influence in Green Performance management and assessment is the characteristic of the company provides feedback on the results of performance appraisal. Feedback from performance appraisal is needed for the next step in managing employee management related to reward, punishment or training.

\section{4) Green Employee retention positively and}

significantly effects Green Performance

Green Employee retention effect on Green Performance which means that good implementation of Green Employee retention in MSMEs will influence the increase of Green Performance. These findings corroborate the results of previous research conducted by Adimuthu Research (2017). The results found that the dominant characteristic of Green Employee retention is to provide openings for staffs to participate in managing green management in the workplace. employee involvement in green management in the workplace will accelerate the process of internalizing green employee behavior.

\section{5) Green Performance positively and significantly}

effects Competitive advantage

Green Performance effect on Competitive advantage. Study results specify that the dominant characteristic of Green Performance is decreasing waste and salvaging in the manufacture practise . The management of the production process that focuses on green will improve the company's environmental performance.

\section{6) Green Performance management and appraisal} positively and significantly effects Competitive advantage

Green Performance management and appraisal effect on Competitive advantage. Study results suggest that Green Performance management and appraisal in SMEs studied is nonetheless not ideal and requires to be increased on Design work focus on green.

7) Green Reward and compensation positively and significantly effects Competitive advantage

Green Reward and compensation effect on Competitive advantage. Study results suggest that Green Reward and compensation in MSMEs studied is nonetheless not ideal and requires to be increased on

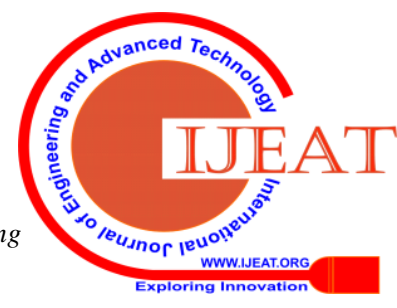


the existence of a programmed compensation system.

8) Green Employee retention positively and significantly effects Competitive advantage

Green Employee retention effect on Competitive advantage. Study results suggest that the dominant characteristic of Research findings indicate that Green Employee retention in MSMEs studied is nonetheless not ideal and requires to be increased on management supports employees to improve green behavior.

9) Green Recruitment and selection positively and significantly effectsCompetitive advantage through Green Performance

The results prove Green Recruitment and selection effect on Competitive advantage through the mediation of Green Performance. Design work, job description, and criteria on process recruitment which focus on the green can affect the Green Performance so that it will cause a Competitive advantage on MSMEs.

10) Green Performance management and appraisal positively and significantly effects Competitive advantage through Green Performance

The results prove Green Performance management and appraisal on Competitive advantage through the mediation of Green Performance. Indicator Green Performance management and appraisal as employees know the target to contribute to environmental management, management includes environmental indicators in performance appraisal, combining the objectives and targets of environmental management in the organization's work evaluation system can improve the Green Performance and Competitive Advantages of MSMEs.

11) Green Reward and compensation positively and significantly effects Competitive advantage through

Green Performance

The results prove the Reward and compensation effect on Competitive advantage via the mediation of Green Performance. Reward system which is associated with Green Performance, the reward for achieving environmental performance and the online programmed compensation system can improve the Green Performance and Competitive Advantages of MSMEs.

\section{CONCLUSION AND RECOMMENDATION}

\section{A. Conclusion}

In Particular, the findings of this research can be reviewed as follows:

1. Green Recruitment and selection; Green Training and development; Green Performance management and appraisal and Green Employee retention directly and positively impact Green Performance.

2. Green Reward and compensation are not significant on Green Performance.

3. Green Performance positively and significantly effect Competitive advantage

4. Green Performance management and appraisal; Green Reward and compensation \& Green Employee retention positively and significantly effect Competitive advantage

5. Green Recruitment and selection \& Green Training and development does not significantly effect Competitive advantage

6. Green Recruitment and selection; Green Performance management and appraisal \& Green Reward and compensation have a positive and significant effect on Competitive advantage through Green Performance

7. Green Training and development \& Green Employee retention does not significantly effect Competitive advantage through Green Performance

\section{B. Recommendations}

1. MSMEs need a strategy to survive in business one of them is to create competitive advantage obtained by improving its ability in making networking and innovation to bring value added. Management of Green Human Resources Management (GHRM) if implemented properly will be a business value added to the competitive advantage of MSMEs. GHRM must be a superior program in order to realize the vision, mission, values, and strategies of MSMEs to improve the growth and sustainability of SME businesses. The government is expected to concern with the development of by creating business regulations to support MSMEs.

2. This study offers hypothetical effects for the improvement of Management Science, especially in the field of Green Human Resources Management and Green Performance. Additional exploration can be organized by expanding the investigation area to understand the reliability of the outcomes and addition of organizational sustainability variables.

\section{ACKNOWLEDGMENTS}

The authors are grateful for MSME around Jakarta which is the object of this research

\section{REFERENCES}

[1] Arulrajah Anton, Opatha, Nawaratne. (2015).Green Human Resource Management Practices: A Review. Sri Lankan Journal of Human Resource Management. Vol.5, No.1, 2015

[2] A P Sarode. (2016). A study of Green HRM and Its Evaluation with Existing HR Practices in Industries within the Pune Region.International Journal of Research in Engineering, IT and Social Sciences ISSN 2250-0558, Impact Factor: 6.452, Volume 6 Issue 04, April 2016

[3] Adimuthu Ramasamy, Ishmael Inore \& Richard Sauna. (2017). A Study on Implications of Implementing Green HRM in the Corporate Bodies with Special Reference to Developing Nations.International Journal of Business and Management; Vol. 12, No. 9; 2017

[4] Bilal Bin Saeed Bilal Afsar, Muhammad Asim Afridi. (2018) Promoting employee's environmental behavior through green human resource management practices.John Wiley \& Sons, Ltd and ERP Environment

[5] Charbel Jose Chiappetta Jabbour,(2011), How green are HRM practices, organizational culture, learning, and teamwork? A Brazilian study. Industrial and Commercial Training, Vol. 43 Iss 2 pp. 98 - 105

[6] Douglas W.S. Renwick, Tom Redman1and Stuart Maguire. (2012) Green Human Resource Management: A Review and Research Agenda.International Journal of Management Reviews, 2012. 
[7] Deepak Bangwal\& Prakash Tiwari. (2015) Green HRM - A way to greening the environment. IOSR Journal of Business and Management (IOSR-JBM) Volume 17, Issue 12 .Ver. I (Dec. 2015), PP 45-53

[8] Guiyao Tang. (2017). Green human resource management practices: scale development and validity.Asia Pacific Journal of Human Resources

[9] Hiba A. Masri, Ayham A.M. Jaaron (2016). Assessing Green Human Resources Management Practices in Palestinian Manufacturing Context: An Empirical Study.Journal of Cleaner Production Dec 2016

[10] H. H. D. N. P. Opatha \& A. Anton Arulrajah, (2014). Green Human Resource Management: Simplified General Reflections.International Business Research; Vol. 7, No. 8; 2014

[11] Jie Shen, Jenny Dumont, and Xin Deng. (2016). Employees Perceptions of Green HRM and Non- Green Employee Work Outcomes: The Social Identity and Stakeholder Perspectives .sagepub.com/journalsPermissions.nav, 2016

[12] Jackson, Susan E., and Renwick, Douglas W. S. and Jabbour, Charbel J. C. and Muller-Camen, Michael (2011) State-of-the-art and future directions for green human resource management: introduction to the special issue. Zeitschrift für Personalforschung, 25 (2). pp. 99-116

[13] Lenny \& Ahmad. (2018). How the Green Human Resources Management (GHRM) process can be adopted for the organization business?, The 1st UPI International Conference on Economics, Business, Entrepreneurship, and Finance
[14] Marco Guerci and Luca Carollo.(2015). A paradox view on green human resource management: insights from the Italian context. The International Journal of Human Resource Management, April 2015

[15] Macro Guerci, Annachiara Longoni, and Davide Luzzini. (2015). Translating stakeholder pressures into environmental performance the mediating role of green HRM practices. The International Journal of Human Resource Management, Sept 2015

[16] Pavitra Mishra. (2017). Green Human Resource Management: framework for sustainable organizational development in an emerging economy.International Journal of Organizational Analysis

[17] Shoeb Ahmad, (2015), Green Human Resource Management: Policies and practices.Cogent Business \& Management (2015), 2: 1030817

[18] Solomon. (2013). Penguatan Metodologi Penelitian Generalized Structured Component Analysis GSCA. Fak. MIPA Universitas Brawijaya. Malang.

[19] Wayne O'Donohue and Nuttaneeya. (2015). The moderating effect of 'Green' HRM on the association between proactive environmental management and financial performance in small firms.The International Journal of Human Resource Management, Aug 2015

[20] Yu-Shan Chen, Ching-Hsun Chang \& Yu-Hsien Lin. (2014). Green Transformational Leadership and Green Performance: The Mediation Effects of Green Mindfulness and Green Self-Efficacy.Sustainability. $4,6,6604-6621$

\section{APPENDIX - A}

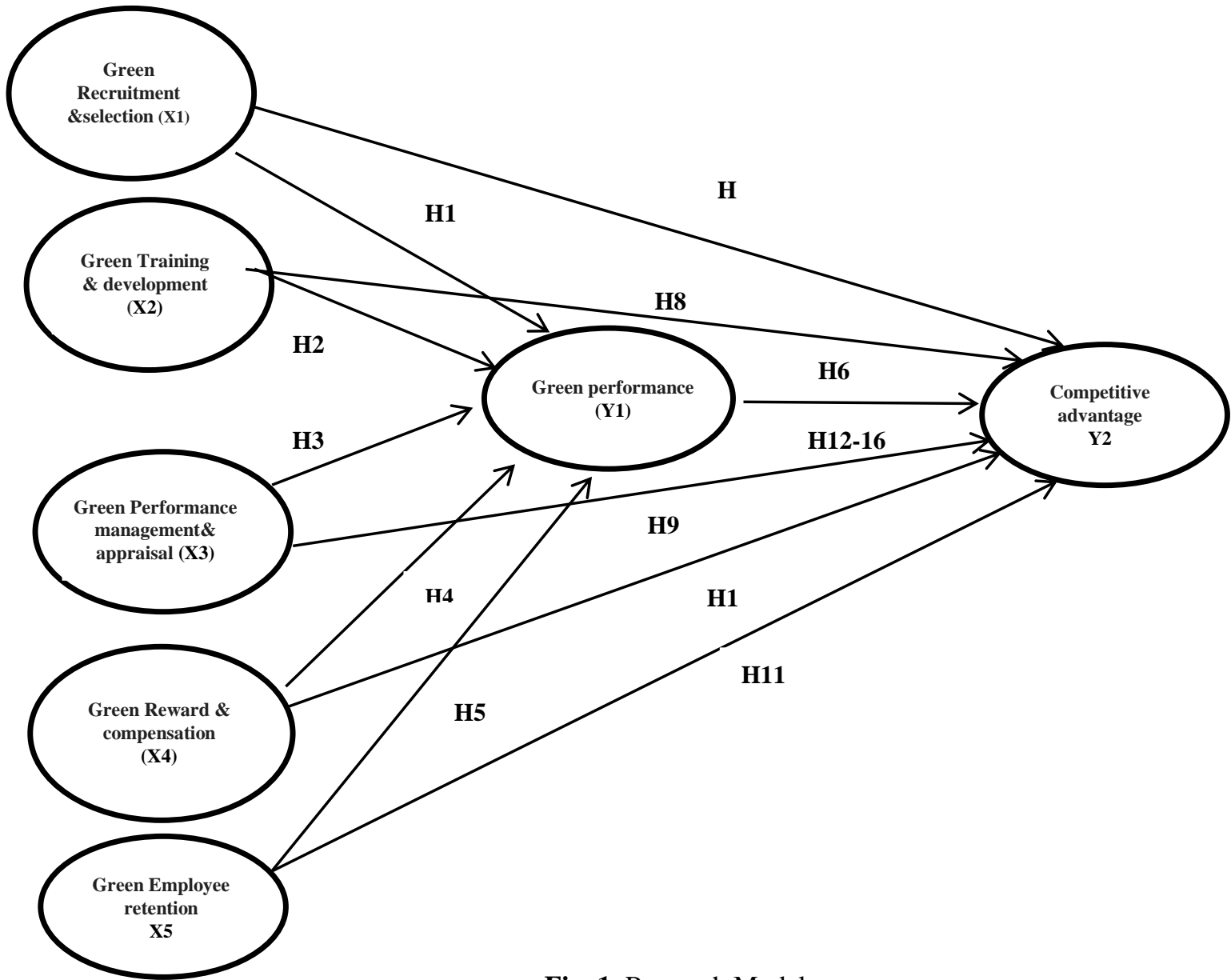

Fig. 1. Research Model 


\section{APPENDIX - B}

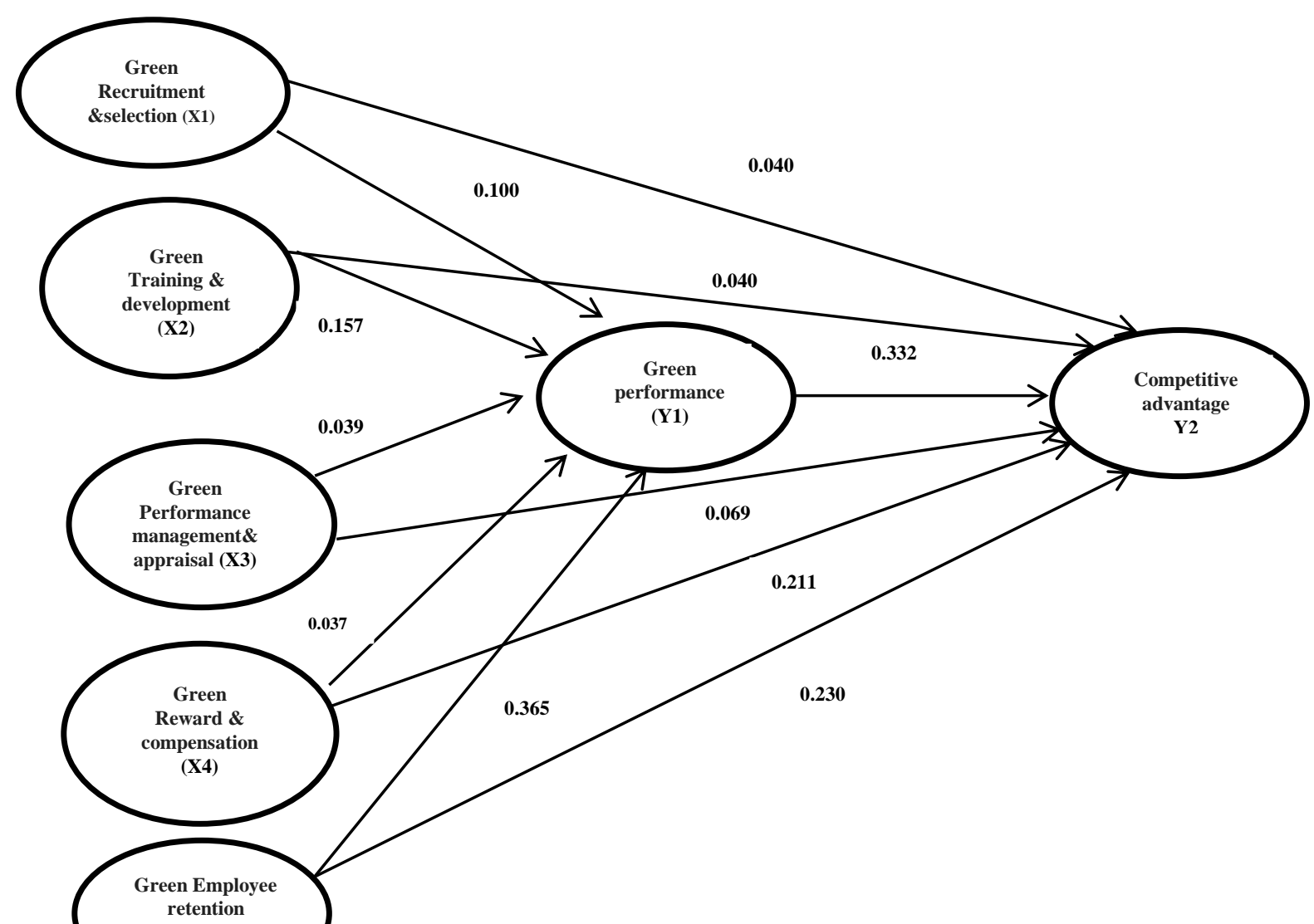

Fig. 2. Path Analysis Model

\section{Authors Profile}

Lenny $C$ awaNngsari,

I am Lenny C awaNngsari currently I am affiliated with Magister Management, Universitas Mercubuana, lenny.nawangsari@ gmail.com Ahmad H Sutawijaya

I am Ahmed H Sutawijaya and I am affiliated with Doctoral Management, Universitas Mercubuana, ahsuta69@gmail.com 